This item was submitted to Loughborough's Research Repository by the author.

Items in Figshare are protected by copyright, with all rights reserved, unless otherwise indicated.

\title{
Editorial introduction: geographies of education and aspiration
}

PLEASE CITE THE PUBLISHED VERSION

http://dx.doi.org/10.1080/14733285.2011.540434

\section{PUBLISHER}

(C) Taylor \& Francis

\section{VERSION}

AM (Accepted Manuscript)

\section{PUBLISHER STATEMENT}

This work is made available according to the conditions of the Creative Commons Attribution-NonCommercialNoDerivatives 4.0 International (CC BY-NC-ND 4.0) licence. Full details of this licence are available at: https://creativecommons.org/licenses/by-nc-nd/4.0/

\section{LICENCE}

CC BY-NC-ND 4.0

\section{REPOSITORY RECORD}

Holloway, Sarah L., Gavin Brown, and Helena Pimlott-Wilson. 2019. "Editorial Introduction: Geographies of Education and Aspiration”. figshare. https://hdl.handle.net/2134/18450. 


\title{
Editorial introduction: Geographies of education and aspiration
}

\author{
Holloway, Sarah L., Brown, Gavin and Pimlott-Wilson, Helena
}

Geographies of children, youth and families have grown from diverse roots -- in developmental psychology, feminism and action research with children -- into the vibrant field of research represented in the pages of this journal (Holloway and Pimlott-Wilson, 2011). The development of the field in the past two decades has also been shaped through its engagement with research in the new social studies of childhood, and a key legacy of this has been the emphasis placed on diverse children's agency within geographical research on/with children (Ansell, 2009; Holloway and Valentine, 2000). Children's geographies has, to a large extent, been a success in early twenty-first century geography, but Aitken’s (2004) editorial in this journal reminds us of the need to be alert to dangers lurking under the surface. The potential dangers facing the sub-discipline are disparate, but here we want to highlight our response to two that have influenced the shape of this special issue.

One danger highlighted by Aitken (2004) is that children’s geographers might relax within their comfort zone, circulating knowledge within a pleasant sub-disciplinary cultural climate, rather than taking the insights of research out into the wider discipline and beyond. This particular concern does not chime with our own experiences of researching geographies of children, youth and families, as we have worked, and see others work, both within the subdisciplinary boundaries and beyond them. Nevertheless we remain alert to the potential pitfalls of sub-disciplinary parochialism, and argue that we need to continue to strive to ensure that the implications of children's geographies are understood in wider intellectual contexts. For us, the fast developing geographies of education is one such arena in which understanding is currently impoverished through a lack of engagement with geographies of children, youth and families. We have argued elsewhere that taking geographies of children, youth and families seriously would foreground young people as the subjects rather than objects of education, demanding that attention is paid to their current and future life-worlds, in geographies of education that transcend the inward/outward looking dichotomy (Holloway et al., 2010). One of the aims of the Geographies of Education Conference, held at Loughborough University in September 2009 and on which this special issue is based, was therefore to promote intellectual connections and bring these two fields of interest into closer 
dialogue.

The traffic in such intellectual debates, however, is far from one way. Just as geographies of education might benefit from insights provided by geographies of children, youth and families, the opposite is also true. Specifically, we think greater engagement with geographies of education might help as children's geographers ponder a second potential danger in the sub-discipline. The risk in question is that children's geographers, in their desire to pay due heed to the importance of children as social actors in their own right, might over emphasise 'empirical studies of the everyday lives of children', whilst underplaying their analysis of 'the wider processes, discourses and institutions to which these connect' (Ansell, 2009: 191). For us this particular risk is really one of degrees rather than absolutes. There is no question that focusing on children's experiences is valuable and that in doing so we have the potential to illustrate the structural constraints under which children live their lives. Equally, however, we recognise that children's geographers also need to do more as these 'processes, discourses and institutions' have received relatively less attention within the sub-discipline than children themselves. In this respect there is much that children's geographers might learn from an engagement with geographies of education (recognising always that this encompasses only one aspect of children's lives) where the restructuring of institutions, and processes such as neoliberalisation, social reproduction and globalisation are more clearly on the agenda (Hanson Thiem, 2009). In this special issue then we propose to bring together studies which engage directly with children, youth and families, and those which explore the importance of wider actors, institutions and processes which influence young people's lives (making some realities a possibility for young people and their families; whilst other potential outcomes remain beyond reach).

The focus of the special issue is on education and aspiration. Education has risen up the political agenda in the Global North as the economic restructuring which began in the 1970s, along with concurrent social changes including the feminisation of the workforce, presented new challenges to established welfare states (Pierson 2006). Jenson and Saint-Martin (2006) argue that there is policy convergence across the Global North as states have responded to the new social risks with a generalised policy vision which emphasises the importance of: learning across the lifecourse; contemporary investment for future social and economic benefit; and economic activity for individual and societal well-being. These shifts in the neo-liberal states’ policy discourse have lead to the prioritisation of education, both as it is 
seen as crucial to developing the advanced human capital needed if states are to be successful in global knowledge economies, and because education for all seems to offer the route to social mobility for aspirational individuals, thus purportedly enhancing social cohesion.

Jeffrey's (2010) review of the role of education as a site of vital conjunctures in young people's lives highlights some of the problems which are glossed over in such policy discourse. Specifically, he shows how education is a contradictory resource for young people in different global contexts -- education is highly valued by young people as it seems to offer them some social opportunities; but, at the same time, it ties them ever more tightly into systems of inequality. A key issue with schemes which seek to enhance participation in education as a route to social mobility is that these individualise the need to raise aspirations, leaving 'the causes for patterns of unequal participation...divorced from the structures and practices that create and frame participation' (Archer, 2007: 643). This contradictory nature of education as a resource, and in particular the ways young people (and their families) are exhorted to change and improve themselves through education without attention to wider structures that reproduce inequality, shapes some of the political ambivalence around education seen in this special issue. Education can be a powerful tool for emancipation. Even schemes which individualise responsibility rather than tackling broader systems of inequality can help some young people. But increasing educational participation and achievement alone is not enough to fundamentally change society. Wider political attention also needs to be paid to economic, social and political structures which reproduce inequality and mean young people of different classes, ethnicities and genders etc are differentially positioned in relation to education, employment and wider senses of well-being.

Despite the current policy consensus across the Global North on the need to prioritise education, there is still considerable divergence in the ways policies designed to enhance education are shaped and implemented within different nation states (Jenson and SaintMartin, 2006). Our purpose in this special issue is to explore how this discourse around aspiration and education has been played out in different parts of the education system in one particular country. Our focus is on Britain under New Labour where Tony Blair was elected after a campaign in which he prioritised 'education, education, education' and this remained core to New Labour economic and social policy throughout their period in government (Whitty, 2009). As Prime Minister, Blair both regarded education as 'our best economic policy' (as a modern education system is seen to produce the flexible citizen-workers of the 
future) but also argued it could 'correct the inequalities of class or background' (Blair, cited in Reay 2008: 644). Over the course of the special issue we want to consider the importance of discourses around aspiration in higher education (see papers by Brown; and Hinton); in the compulsory years of schooling (see papers by Bright; Butler and Hamnett; Holloway and Pimlott-Wilson; and Purcell); and in diverse forms of family-based learning (see papers by Wainwright and Marandet; and Pimlott-Wilson).

Our aim in exploring the diverse ways in which these discourses about education and aspiration have played out in different sections of the education system is three-fold. Firstly, we want to explore the roles of different institutions and actors in shaping and implementing neo-liberal education policies which affect the lives of young people and their families. We are interested in how developments in neo-liberal discourse filter down into different educational settings, how they are understood and potentially transformed by different actors there, shaping the particular form policies take in different settings, and thereby reworking the implications of these policies, both for individuals, and more broadly for the nature of neo-liberal states. This theme can be seen in a number of papers. Brown traces how young people's aspirations are mobilised in policy initiatives to widen access to higher education, how these policies are interpreted and enacted by education practitioners, and how the young people whose aspirations are acted on through these initiates experience them. Purcell by contrast focuses on school education, and considers how discourses about the Academy schools programme in England have been constructed, contested and strategically reworked at the level of national policy making, and within school communities where Academies were proposed, thereby highlighting the connections between these different spatial scales. Wainwright and Marandet concentrate on family learning to explore how courses run to strengthen parents' numeracy and literacy, as well as their parenting skills and community participation, become transformed through the experiences of mothers, most of whom are recent migrants to the UK, into a collective space where aspirations for belonging can be explored, defined and worked through. Pimlott-Wilson's paper stands out as the educational institution she considers is not a formal learning space, but rather the family. The contribution she makes is to remind geographers of education that learning also takes place outwith our formalised structures of schooling, further and higher education, as the experience of growing up in families with different working arrangements influences children's aspirations for education and employment. 
Secondly, we are hoping to further incorporate young people and their families into geographies of education by producing class-differentiated and regionally-specific analyses of parents' and young people's aspirations for education. Hinton explores the importance of national identity in shaping young Welsh people’s aspirations around higher education. Butler and Hamnett show how the intersections of class and ethnicity work out in one very specific context, as they trace the importance of gentrification on experiences of access to school education in London. Holloway and Pimlott-Wilson explore the reasons why primary school head teachers define parents' aspirations for their children as unsuitable in low-income provincial Britain, and uncover the ways they seek to raise children's aspirations through formal education and activities with parents and children in the wider community setting. Bright, by contrast, investigates white working class masculinity and femininity, as he traces the resistant aspirations of young people who have dropped out of formal education in a deindustrialised landscape.

Thirdly, we hope to show how young people's and their families' aspirations exceed the limits of the discourse on aspiration identified in neo-liberal policy discourse. On the one hand, the papers demonstrate that parents and young people's aspirations extend beyond success in moving into higher education and later the labour market, and include, instead of or alongside this, significant emphases on young people’s emotional well-being (Brown; Holloway and Pimlott-Wilson), and their relationships with (future) partners and children (Bright; Brown). These papers remind us that aspirations are affective, emotional states and that interventions around individual's aspirations have wider emotional consequences. In this sense we see the importance of attending to the emotional geographies of education and aspiration coming through from research participants. Although neo-liberal policy debates about creating aspirational future citizen-workers are frequently infused with highly emotive language and generic statements about promoting well-being, serious consideration of the emotional effects of these initiatives are largely absent from the policy agenda.

On the other hand, the papers also demonstrate the importance of aspirations in shaping policy and practice beyond education. For while debates about aspiration are designed to improve young people's (and their parents') attainment, and facilitate movement into higher education and the labour market, aspirations surrounding education are also reshaping: the 
nature of our urban environments through the housing market (Butler and Hamnett); geographies of migration and migrants’ feelings of belonging (Hinton; Wainwright and Marandet); and children's use of time, as increasing numbers of children engage in formalised ‘edutainment’ activities (Holloway and Pimlott-Wilson).

We do, however, see this special issue as the start of an engagement between geographies of children, youth and families and geographies of education on the topic of aspiration rather than an endpoint. Our focus here has been on how debates about aspiration play out in different parts of the education system in one particular advanced capitalist economy. This country itself has recently experienced a change of government. Initial signs suggest that the discourse of aspiration and achievement of social mobility through individual achievement will continue under the Conservative-Liberal-Democrat coalition, though drastic reductions in public expenditure particularly in higher education, but also in non-core elements of compulsory education, will mean funding for policies designed to raise aspirations is at risk. Though this focus on England and Wales is useful in allowing us to explore how the discourses appear in different aspects of one education system, there is clearly more to be said about how these debates emerge in other welfare states which are currently being reformed, as well as much to be discerned about how the discourse of aspiration travels and plays out in other specific contexts (Jeffrey, 2010; Warrington, 2010). Within these more diverse spatial contexts, there is also scope to consider how a wider range of intersections of identity come together to shape, and be reshaped by, understandings of education and aspiration. Cross-cutting this need for research into a broader range of people, in different places around the globe, is the need to pay continuing attention to the ways in which parents' and young people’s aspirations exceed the neo-liberal policy agenda by investing hope in other mundane and extraordinary futures (Brown, this issue; Kraftl, 2009). Our hope is, that as geographers expand their studies of education and aspiration, they will not only extend emerging critiques of how young people's aspirations have become the object of neoliberal policy interventions, but will also delink the strong association of aspirations with material wealth, educational qualifications and professional employment to explore the range of potential futures that children aspire to realise.

\section{References}

Aitken, S. C., 2004. Editorial: from dismissals and disciplinary inclusions; from block 
politics to panic rooms. Children's Geographies, 2(2), 171-175.

Ansell, N., 2009. Childhood and the politics of scale: descaling children's geographies? Progress in Human Geography, 33(2), 190-209.

Archer, L., 2007. Diversity, equality and higher education: a critical reflection on the ab/uses of equity discourse within widening participation. Teaching in Higher Education, 12(5-6:), 635-653.

Hanson Thiem, C., 2009. Thinking through education: the geographies of contemporary educational restructuring. Progress in Human Geography, 33, 154-173.

Holloway, S.L., Hubbard, P.J., Jöns, H. and Pimlott-Wilson, H., 2010. 'Geographies of education and the importance of children, youth and families’ Progress in Human Geography, 34.5, 583-600.

Holloway, S.L. and Pimlott-Wilson, H., 2011. Geographies of children, youth and families: defining achievements, debating the agenda. In L. Holt, L. (Ed.) Geographies of Children, Youth and Families: an International Perspective. Routledge, London, 9-24.

Holloway, S.L. and Valentine, G., 2000. Spatiality and the new social studies of childhood. Sociology, 34, 763-783.

Jeffrey, C., 2010. Geographies of children and youth I: eroding maps of life. Progress in Human Geography, 34.4, 496-505.

Jenson, J. and Saint-Martin, D, 2006. Building blocks for a new social architecture: the LEGO ${ }^{\mathrm{TM}}$ paradigm of an active society. Available from: http://www.cccg.umontreal.ca/pdf/997 jenson rev 03, last accessed 1.11.10. (Also published in Policy and Politics 2006, 34.3: 429-451).

Kraftl, P., 2009. Utopia, childhood and intention. Journal for Cultural Research, 13(1), 69-88.

Pierson, C., 2006. Beyond the welfare state?: the new political economy of welfare. $3^{\text {rd }}$ Edition. Cambridge, Polity Press.

Reay, D., 2008. Tony Blair, the promotion of the 'active' educational citizen, and middle- 
class hegemony. Oxford Review of Education, 34, 639-50.

Warrington, M., 2010. Girls against the odds. Paper presented at the Royal Geographical Society/Institute of British Geographers Annual Conference, $1^{\text {st }}-3^{\text {rd }}$ September, 2010, London.

Whitty, G,. 2009. Evaluating 'Blair's Educational Legacy?’: some comments on the special issue of Oxford Review of Education. Oxford Review of Education, 35, 267-80. 